УДК 656.13:339.13

\title{
СУЧАСНИЙ СТАН ВПРОВАДЖЕННЯ ЛОГІСТИКИ НА ЗАЛІЗНИЧНОМУ ТРАНСПОРТІ УКРАЇНИ
}

\author{
Д-р техн. наук Д.В. Ломотько, асп. О.Ю. Кривич \\ СОВРЕМЕННОЕ СОСТОЯНИЕ ВНЕДРЕНИЯ ЛОГИСТИКИ НА \\ ЖЕЛЕЗНОДОРОЖНОМ ТРАНСПОРТЕ УКРАИНЫ
}

Д-р техн. наук Д.В. Ломотько, асп. О.Ю. Кривич

\section{CURRENT STATUS OF IMPLEMENTATION OF LOGISTICS OF THE RAILWAYS OF UKRAINE}

\author{
Dr. techn. science D. Lomotko, postgraduate O. Krivich
}

Було проаналізовано роботу «УТЛЦ» (Український транспортно-логістичний иентр) за дев'ять місяців 2013 року, виділені основні недоліки та шляхи подальшого підвищення ефективності використання рухомого складу.

Ключові слова: логістика, логістичне управління, логістичний центр, матеріальний потік, інформачійний потік, ринкова економіка, якість транспортного обслуговування, господарська діяльність, інтеграчійний підхід.

Проанализирована работа «УТЛЦ» (Украинский транспортно-логистический иентр) за девять месяиев 2013 года, выделены основные недостатки и пути дальнейшего повышения эффективности использования подвижного состава.

Ключевые слова: логистика, логистическое управление, логистический центр, материальный поток, информаџионный поток, рыночная экономика, качествотранспортного обслуживания, хозяйственная деятельность, интеграчионный подход.

The operation of "UTLC" (Ukrainian transport and logistics center) for the first 9 months of 2013 was analyzed, was found the main shortcomings and ways to further improve the using of rolling stock. During the first 9 months of 2013 in carriages with a sign SE "UTLC" was transported 105.6 million tons, more than the previous year by 0.4\%. It should be noted that last year was a time of formation UTLC and period of conversion the property of the state railway companies. Today in operating UTLC is: over 45 thousand of gondola, more than 6 thousand covered carriages, including working park - over 5 thousand carriages.

Keywords: logistics, logistics management, logistics center, material flow, information flow, market economy, quality of service and transport, economic activity, the integration approach.

Вступ. Сучасною тенденцією розвитку i вдосконалення транспортної системи стало поширення логістики, логістичного управління, тобто всього комплексу послуг зі швидкої та якісної доставки товарів. Зростаюча вартість факторів виробництва, зокрема робочої сили, інфраструктури, в багатьох країнах призводить до неефективності виробництва на національному рівні та сприяє переведенню його в інші країни. Визначальною стратегією діяльності на світових ринках $є$ чіткість та висока швидкість оформлення угод. Іншими словами, ключовим моментом діяльності в 
розвинених суспільствах стає посилена роль логістики.

Постановка проблеми у загальному вигляді та іiї зв'язок із важливими науковими та практичними завданнями. У число факторів, що визначають конкурентоспроможність продукції, крім ціни, входить організація швидких поставок, i це нерідко виявляється важливішим ціни. Відсутність гарантії на своєчасну доставку продукції призводить до відмови від угод незалежно від інших умов, у тому числі цінових. Відбулася зміна акцентів у ринковому попиті з більш низьких цін і значних запасів продукції на фактор часу, широку номенклатуру продукції, якісні показники. Конкурентні переваги компаніям дає логістичне управління, тобто повний пакет послуг при супроводі товару, що включає також інформацію про стан, місцезнаходження товару в реальний момент часу. При цьому вартість послуги (продукції) зростає через відсутність або затримки інформації [1].

Вичерпання потенціалу ефективності багатьох галузей пояснюється значним тимчасовим інтервалом між видобутком сировини і реалізацією продукції. Так, у промисловості країн Західної Європи він становить близько $2 \%$ загального часу виробництва, на транспорті - 5\%, $93 \%$, що залишилися, припадають на різні стадії зберігання i переробки. Логістичний ланцюжок дозволяє подолати розрив, інтегруючи в загальний виробничий процес транспортно-закупівельну функцію [2].

Аналіз останніх досліджень i публікацій. Останніми роками 3'явилось чимало публікацій, які присвячені проблемам формування і функціонування логістичних систем. Під якісно новим кутом зору аналізується логістика професором MIITy (м. Москва) Ф.М. Трихунковим [3]. Суть досліджень Т.В. Бутько полягає у розв'язанні задачі оптимального розміщення у вузлі логістичного центру та виборі його параметрів [4]. Питання оптимізації логістичних підходів розкриті у численних публікаціях А.М. Гаджинського [5], В.Я. Негрея [6].

Визначення мети та задачі дослідження. Метою публікації $\epsilon$ аналіз існуючого стану впровадження логістики на залізничному транспорті, адже розгляд підприємства 3 точки зору логістичної організації допомагає керувати процесами створення цінностей 3 прийнятними для споживача витратами.

Основна частина дослідження. 3 початку XXI століття на українських залізницях зі створення логістичних центрів проводиться інтенсивна робота. Логістичні центри - це організаційнопідприємницькі структури 3 найбільш прогресивними способами надання вантажовідправнику повного комплексу транспортних послуг [7].

Державне підприємство "Український транспортно-логістичний центр" (ДП "УТЛЦ"), що було створене у листопаді 2011 року, на підставі договорів 3 власниками рухомого складу i вантажовідправниками здійснює оперування парком вагонів державних вагонних компаній на території України. Пріоритетним завданням для нього $\epsilon$ задоволення всіх заявок на перевезення, що надходять від вантажовласників, а також оптимізація перевізного процесу для мінімізації порожнього пробігу і обороту вагонів [8].

За дев'ять місяців 2013 року у вагонах із ознакою ДП «УТЛЦ» було перевезено 105,6 млн т, що більше минулорічного показника на $0,4 \%$.

Станом на 30.09.2013 року укладено 999 договорів, у тому числі:

- про надання послуг 3 організації перевезень вантажів у власних напіввагонах - 522;

- про надання послуг 3 організації перевезень вантажів у власних критих вагонах - 331; 


\section{Експлуатація залізниць}

- про надання послуг 3 організації перевезень вантажів на власних транспортерах - 18;

- про надання послуг 3 організації перевезень транзитних вантажів територією України у власних напіввагонах -61 ;

- про надання послуг з організації перевезень транзитних вантажів територією України у власних критих вагонах - 51 [8].
На сьогоднішній день в оперуванні УТЛЦ знаходиться: понад 45 тис. напіввагонів, 3 них у робочому парку більше 32 тис., понад 6 тис. - криті вагони, у тому числі в робочому парку - понад 5 тис. вагонів [9].

На рис. 1 наведені дані щодо навантаження вагонів УТЛЦ на Південній залізниці за основними видами номенклатури вантажів.

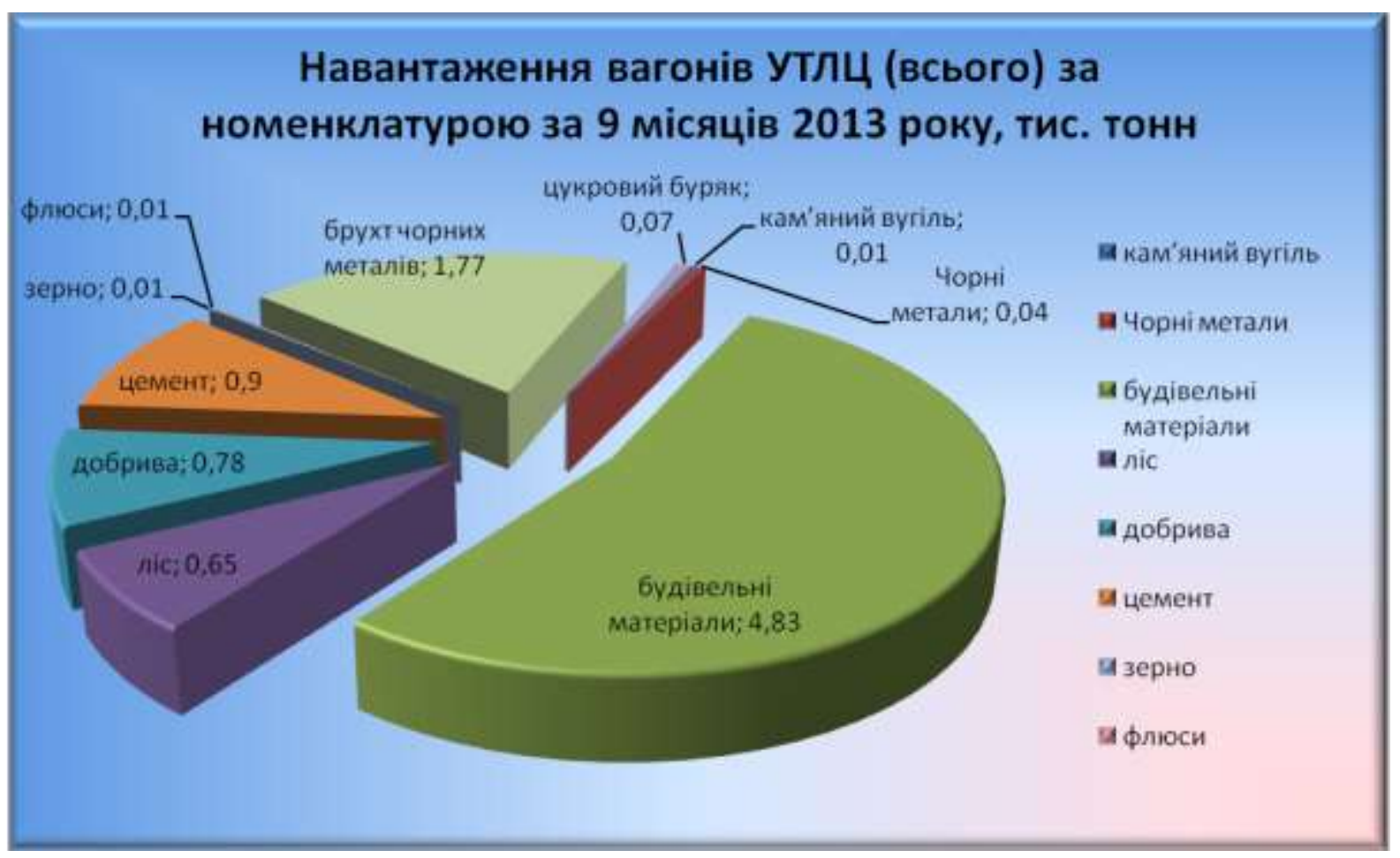

Рис. 1. Навантаження вагонів за номенклатурою вантажів, тис. т

Найбільша частка припадає на будівельні матеріали, ліс, брухт, цемент та добрива.

Слід зауважити, що минулий рік був часом становлення УТЛЦ та періодом переведення рухомого складу у власність державних вагонних компаній. Адже створювалася безліч всіляких логістичних схем для найбільш ефективного використання вагонів. Всі ці схеми мають тенденцію до зміни, адже логістика українських підприємств постійно розвивається, відповідно необхідне коригування напрямків перевезень. Також у цей період відбувалося переведення рухомого складу у власність державних вагонних компаній. Іншими словами, формувався парк, яким сьогодні оперує центр [9].

Так, власниками українських напіввагонів став ДП "Дарницький вагоноремонтний завод" (ДП " ДВРЗ") та ДП "Український державний центр 3 експлуатації спеціалізованих вагонів" (ДП "Укрспецвагон"), які разом 3 вагонами отримали також у своє розпорядження серйозну ремонтну базу, дислоковану в регіоні масового навантаження на 
Донецькій і Придніпровській залізницях. Крім того, підприємства мають ліцензії на будівництво нового рухомого складу i необхідні потужності для його виробництва [8].

Більше 10 тисяч критих вагонів знаходяться у власності Державного підприємства "Український державний центр залізничних рефрижераторних перевезень "Укррефтранс" (ДП УДЦЗРП "Укррефтранс"), який виконує плановий i капітальний види ремонтів цих вагонів 3 продовженням їх терміну служби, а також виконує програму зі збільшення парку власних критих вагонів [8].

Спеціалізований рухомий склад, а саме мінераловози, хопер - цементовози, вагони - термоси і цистерни знаходяться у власності ДП "Стрийський вагоноремонтний завод" (ДП "СВРЗ").

Власні транспортери знаходяться у власності Державного підприємства
"Український державний центр транспортного сервісу "Ліски" (ДП "УДЦТС "Ліски") [8].

Одним із важливих комплексних якісних показників роботи залізниці є обіг вагона, який відображає результати технічної, економічної та організаторської діяльності усіх ланок залізниці.

На рис. 2 подано обіг вагона УТЛЦ у розрізі всіх його складових за дев'ять місяців 2012 та 2013 років (дані наведені по Південній залізниці).

3 нижченаведеного рисунка видно, що загалом обіг вагона УТЛЦ на Південній залізниці уповільнений на 0,25 доби за рахунок уповільнення обігу порожнього вагона. У той час як обіг навантаженого вагона скорочений за рахунок усіх його складових (обігу місцевого та транзитного вагона).

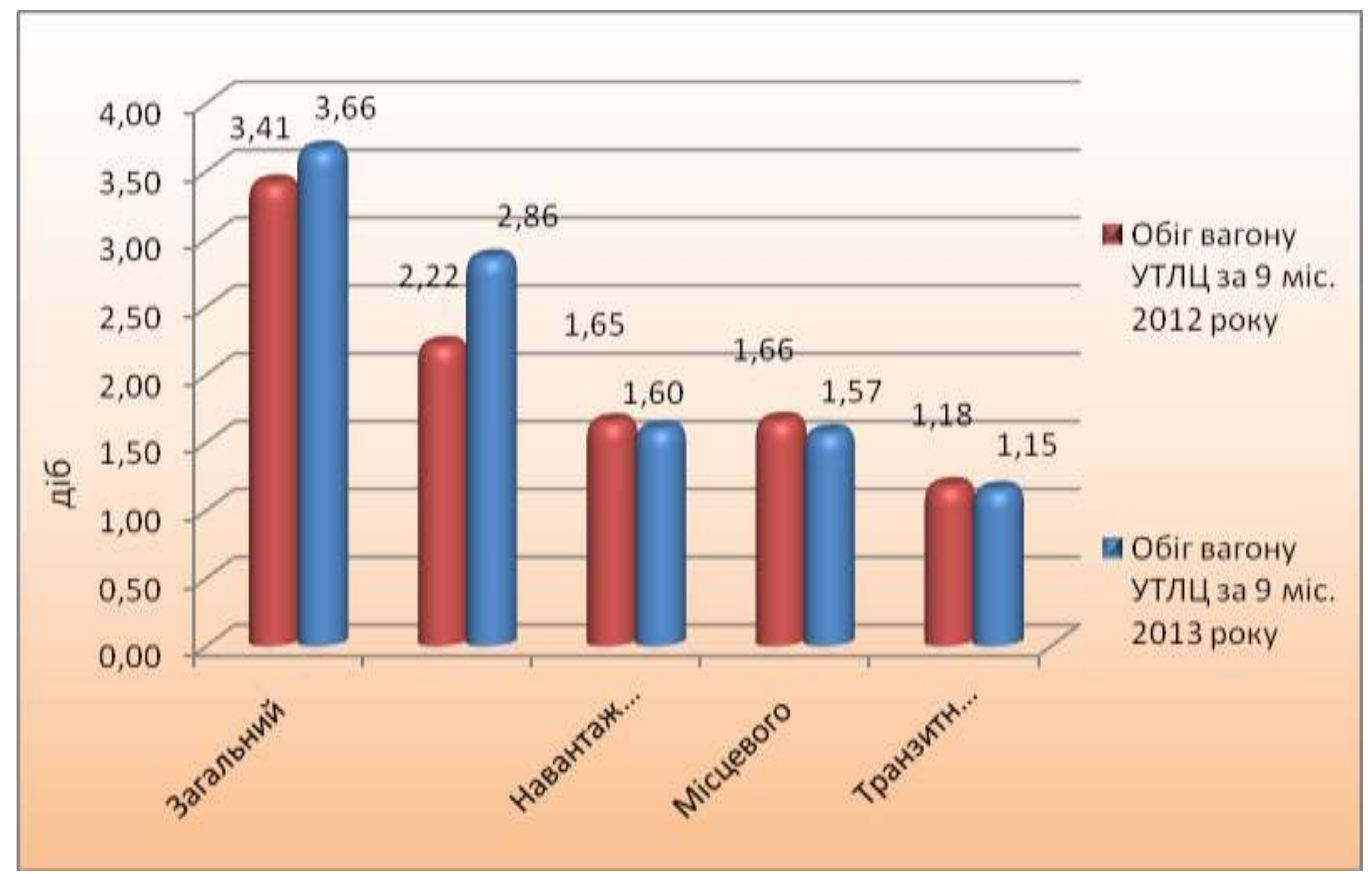

Рис. 2. Обіг вагона за дев'ять місяців 2012 та 2013 років, сер./доб

Обіг порожнього вагона - це час знаходження вагона у порожньому стані на підрозділі. Він визначається як частка від ділення робочого парку порожніх вагонів на роботу порожніх, тобто на суму навантаження та здавання порожніх вагонів до сусідньої залізниці [10]: 


$$
\vartheta_{\text {пор }}=\frac{n_{\text {пор }}}{\mathrm{u}_{\text {пор }}}=\frac{n_{\text {пор }}}{\mathrm{U}_{\mathrm{H}}+\mathrm{U}_{\text {зд }}^{\text {пор }}}
$$

де $\vartheta_{\text {пор }}$ - обіг порожнього вагона;

$n_{\text {пор }}$ - кількість порожніх вагонів у робочому парку;

$\mathrm{U}_{\text {пор }}$ - робота порожніх вагонів;

$\mathrm{U}_{\mathrm{H}}$ - навантаження;

$\mathrm{U}_{\text {зд }}^{\text {пор }}-$ здавання порожніх вагонів.

За умови незмінності усіх інших складових обігу порожнього вагона зниження утримання робочого парку порожніх вагонів у порівнянні з 2012 роком на 14,5\% призвело до прискорення обігу порожнього вагона на 0,32 доби. У той час як зменшення навантаження на $37,3 \%$ уповільнило обіг порожнього вагона на 0,43 доби, а зменшення здачі порожніх вагонів на 30,8\% - на 0,47 доби.

Тож можна зробити висновок, що частка впливу роботи порожнього вагона (навантаження та здавання порожніх) $\epsilon$ більшою за робочий парк, і саме зменшення роботи, головним чином, призвело до уповільнення обігу.

Кількість перевитрачених вагоногодин у зв'язку із збільшенням обігу вагона можна визначити за формулою [10]

$$
\Pi=\mathrm{U}\left(\vartheta^{r}-\vartheta^{I}\right),
$$

де $\mathrm{U}$ - робота залізниці;

$\vartheta^{r}$ - фактичне виконання обігу вагона (год);

$\vartheta^{F}$ - планове завдання обігу вагона (год);

$\Pi=564(87,84-81,84)=3384$ ваг.год.

Висновки 3 дослідження i перспективи, подальший розвиток $\mathbf{y}$ даному напрямку. Прискорення обігу вагона - найважливіше завдання у боротьбі за поліпшення роботи залізничного транспорту. Шляхи подальшого прискорення обігу вагона - скорочення навантаженого рейсу вагона шляхом усунення нераціональних перевезень; скорочення порожнього пробігу вагонів ; комплексна механізація навантажувальнорозвантажувальних робіт і скорочення простою вагонів під вантажними операціями ; подальше підвищення швидкості руху вантажних поїздів; скорочення їх простоїв на станціях; формування поїздів 3 максимальною вантажною масою, вдосконалення всієї системи управління залізничним транспортом.

Підвищити ефективність роботи насамперед допоможе забезпечення максимальної маршрутизації 3 боку вантажовідправників. Хоч на теперішній день усі традиційні напрямки максимально маршрутизовані, але ще залишається резерв - прискорити обіг вагона дозволить формування східчастих маршрутів 3 декількох пунктів навантаження. Окрім того, необхідно посилити уже наявну маршрутизацію порожніх вагонів, оскільки вона не завжди відбувається оптимальнорозбірні поїзди 3 включенням порожніх вагонів нерідко йдуть 3 переробкою на одній-двох, а іноді й трьох гірках сортувальних станцій, що затримує вагони у русі [9].

На нинішньому етапі дуже важливо, щоб постійні напрямки перевезень клалися на жорсткі графікові нитки. Це дасть можливість усім учасникам перевезень чітко розуміти, коли рухомий склад відправиться $з$ пункту навантаження і коли прибуде в пункт вивантаження. Таким чином, жорстка графікова дисципліна дозволить уникнути непродуктивного простою вагонів. Такий захід, 3 одного боку, підвищить ефективність роботи, а 3 іншого - «УТЛЦ», як державний перевізник, продемонструє вантажовід- 


\section{Експлуатація залізниць}

правникам свої можливості щодо терміналів доставки вантажів.

Також однією 3 головних задач $\epsilon$ забезпечення контролю за вірогідністю електронних заявок клієнтів на подачу вагонів під навантаження та адресне їх забезпечення [9].

\section{Список використаних джерел}

1. Плужников, К.И. Транспортные условия контрактов, транспортная продукция и цена товара [Текст] / К.И. Плужников, Ю.А. Чунталова // Бюллетень транспортной информации (БТИ). - 2002. - № 7. - С. 45.

2. Левиков, Г.А. Глобализация мировой экономики и логистика [Текст] / Г.А. Левиков // Бюлл. транспортной информации (БТИ). - 2002. - № 8. - С.112.

3. Трихунков, Ф.М. Транспортное производство в условиях рынка. Качество и эффективность [Текст] / Ф.М. Трихунков. - М.: Транспорт, 2003.

4. Бутько, Т.В. Удосконалення процесу забезпечення групами порожніх вагонів припортового залізничного вузла [Текст] / Т.В. Бутько, О.О. Берко // зб. наук. праць. Харків: УкрДАЗТ, 2010. - Вип. 112. - С. 1-8.

5. Гаджинский, А.М. Практикум по логистике [Текст] / А.М. Гаджинский. - М.: Издательско-книго-торговый центр «Маркетинг», 2001.

6. Негрей, В.Я. Комплексная механизация и автоматизация погрузочно-разгрузочных и складских работ на железнодорожном транспорте [Текст]: учеб. пособие / В.Я. Негрей, Н.П. Берлин, Н.П. Негрей; [М-во образования Респ. Беларусь, Белорус. гос. ун-т трансп.]. Гомель: БелГУТ, 2010. - 227 с.

7. Гриценко, С.И. Логистическое инновационное обеспечение стратегии развития железнодорожного транспорта Украины [Текст] / С.И.Гриценко // Российское предпринимательство. - 2006. - № 1 (73). - С. 73-78.

8. Транспортно-логістичний центр [Електронний ресурc]. - Режим доступу: www/URL: http://www.pz.gov.ua.

9. Андреева, Л.А. Жизнь от «колеса»// Магистраль. - № 69 (1855), 11-17 вересня 2013 p. - C. 5.

10. Вергун, О.Ф. Рекомендації з техніко-економічних розрахунків експлуатаційної роботи залізниць [Текст] / Розроб.: О.Ф.Вергун, Н.В.Липовець, Л.Ю.Гаркуша. - К.: Транспорт України, 2002. - 64 с.

\footnotetext{
Ломотько Денис Вікторович, д-р техн. наук, професор, Українська державна академія залізничного транспорту. Тел. (057) 771-46-83. E-mail: den@kart.edu.ua Кривич Ольга Юріївна, аспірант кафедри управління вантажною та комерційною роботою Української державної академії залізничного транспорту. Тел. (057)730-10-85. E-mail: oljushka_k@mail.ru

Lomotko Denis V., дr sc. , professor, Ukrainian State Academy of Railway Transport. Tel. (057) 771-46-83. E-mail: den@kart.edu.ya

Krivich Olga, postgraduate chair of management of freight and commercial work Ukrainian State Academy of Railway Transport. Tel. (057) 730-10-85. E-mail: oljushka_k@mail.ru
} 